\title{
PCR detection and serotyping of enterotoxigenic and shigatoxigenic Escherichia coli isolates obtained from chicken meat in Mumbai, India
}

\author{
R. J. Zende, D. M. Chavhan, P. R. Suryawanshi, A. K. Rai and V. M. Vaidya \\ Department of Veterinary Public Health, \\ Bombay Veterinary College, Maharashtra Animal and Fishery Sciences University, \\ Parel, Mumbai-400012, Maharashtra, India \\ Corresponding author: R. J. Zende, email: ravindrazende@gmail.com \\ Received: 02-05-2013, Revised: 09-07-2013, Accepted: 12-07-2013, Published online: 19-08-2013
}

doi: 10.14202/vetworld.2013.770-773 How to cite this article: Zende RJ, Chavhan DM, Suryawanshi PR, Rai AK and Vaidya VM (2013) PCR detection and serotyping of enterotoxigenic and shigatoxigenic Escherichia coli isolates obtained from chicken meat in Mumbai, India, Veterinary World 6(10): 770-773.

\begin{abstract}
Aim: Present study was undertaken to find out the frequency of few virulent genes and prevalence of related strains of Escherichia coli isolated from chicken meat obtained from chicken retail shops by Polymerase Chain Reaction (PCR).

Materials and Methods: 66 samples of freshly slaughtered chicken meat were collected from 22 identified retail shops located at Mumbai city, randomly. Processed meat samples were cultured in EMB agar and presumptive colonies were confirmed by various biochemical tests. PCR method was accustomed for identification of the genes coding for heat-stable enterotoxin a (STa), heat labile enterotoxin (LT), shiga-like toxins 1 and 2 (SLT1 and SLT2). E. coli isolates were sent to National Salmonella and Escherichia Centre, CRI, Kasauli, HP, India for serotyping.

Results: $11(16.67 \%)$ E. coli strains were isolated from 66 chicken meat samples. $3(27.27 \%)$ out of 11 harbored the gene for SLT2, and 2 (18.18\%) for STa. None of the strain contains SLT1 and LT genes. Serotypes detected were rough, O2, O20, O22, O102 each for one isolate and 6 isolates were untypable (UT).

Conclusion: The results concluded that chicken meat samples analysed harbored genes for shiga like toxins and enterotoxins and different serotypes of $E$. coli. These findings indicating that regular monitoring of chicken meat is essential for this pathogen to prevent potential public health problems.
\end{abstract}

Keywords: chicken meat, enterotoxin, Escherichia coli, polymerase chain reaction, virulence gene

\section{Introduction}

Escherichia coli strains are usually recovered from intestinal tracts of human, poultry, animal and commonly present in soil, water and foods due to faecal contamination or contamination during food animal slaughter. They are commonly present in nature and has major role in maintaining equilibrium of intestinal physiology of poultry [1]. Some E. coli strain causes several human diseases like haemolytic uremic syndrome (HUS), haemorrhagic colitis (HC) etc. and various isolates established as major pathogen for poultry colibacillosis [2, 3]. It is recognized as major pathogen for public health problems in developing countries and represents leading etiological agent of diarrhea [4].

Several classes of $E$. coli, specifically enteropathogenic $E$. coli (EPEC), enteroinvasive $E$. coli (EIEC), enterotoxigenic E. coli (ETEC), Shigalike toxin-producing $E$. coli (STEC) or enterohaemorrhagic E. coli (EHEC) or verotoxin producing $E$. coli (VTEC), enteroaggregative $E$. coli (EAggEC) have been recognized [4]. Enterotoxigenic $E$. coli infection owing to ingestion of contaminated food or water produces abdominal cramps, low-grade

Copyright: The authors. This article is an open access article licensed under the terms of the Creative Commons Attribution License (http://creativecommons.org/licenses/by/2.0) which permits unrestricted use, distribution and reproduction in any medium, provided the work is properly cited. fever, watery diarrhea and nausea [5]. Heat-stable (ST) and heat labile (LT), these two enterotoxins, produced by this category plays a distinct role in the pathogenesis. Two classes of heat-stable toxins, STa (STI) and STb (STII), differ structurally and functionally. The genes encoding both these toxins are present on plasmids [6]. Shiga-like toxin-producing $E$. coli strains, responsible for HUS, HC, diarrhea and renal failure in children, are zoonotic water and food borne pathogens [7]. Previous reports revealed that most outbreaks of HUS and HC are caused by serotype E. coli O157:H7 [8]. STEC produces two types of shiga-toxins, SLT1 and SLT2. These toxins have similar biological functions, molecular structure and encode different set of genes in which most of genes are virulence associated so that STEC contaminated food could be at risk for public health. There are several techniques for detection of toxins in which PCR widely taken for targeting SLT-specific genes in many studies $[9,10]$. Therefore, this study was designed taken to find out the frequency of ETEC and STEC virulent genes isolated from chicken meat slaughtered in the retail chicken shops by PCR method.

\section{Materials and Methods}

Sample collection: In present study, 22 identified retail shops \{licensed by Brihanmumbai Municipal Corporation (BMC) $\}$ were selected from Mumbai city 
Table-1. Oligonucleotide primer sets used in PCR

\begin{tabular}{|c|c|c|c|c|}
\hline Gene & Sequence (5'-3') & $\begin{array}{l}\text { Annealing } \\
\text { temp. }\left({ }^{\circ} \mathrm{C}\right)\end{array}$ & $\begin{array}{l}\text { Product } \\
\text { size (bp) }\end{array}$ & References \\
\hline $\begin{array}{l}\text { SLT1 } \\
\text { SLT2 } \\
\text { STa } \\
\text { LT }\end{array}$ & $\begin{array}{l}\text { F-GAAGAGTCCGTGGGATTACG (20) } \\
\text { R-AGCGATGCAGCTATTAATAA (20) } \\
\text { F-TTAACCACACCCACGGCAGT }(20) \\
\text { R-GCTCTGGATGCATCTCTGGT }(20) \\
\text { F-GGGTTGGCAATTTTATTTCTGTA (24) } \\
\text { R-ATTACAACAAAGTTCACAGCAGTA (24) } \\
\text { F-TAGAGACCGGTATTACAGAATCTGA (26) } \\
\text { R-TCATCCCGAATTCTGTTATATATGTC (26) }\end{array}$ & $\begin{array}{l}55 \\
59 \\
59\end{array}$ & $\begin{array}{r}130 \\
346 \\
183\end{array}$ & $\begin{array}{l}12 \\
13\end{array}$ \\
\hline
\end{tabular}

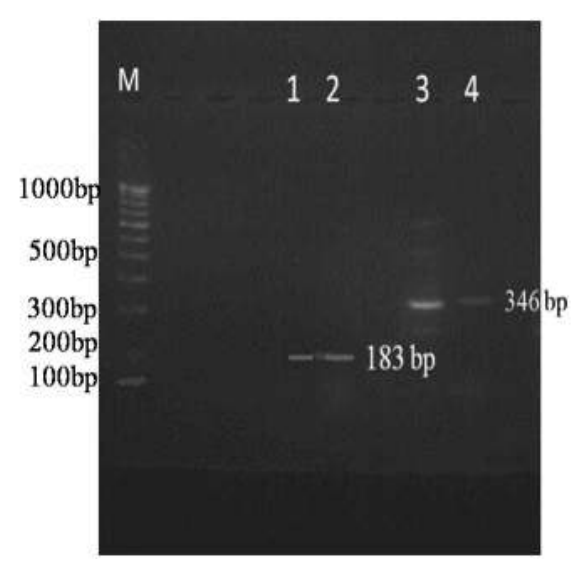

Figure-1. SLT2 gene and STa gene of E. coli Lane M: 100 bp ladder

Lane $1 \&$ 2: STa gene, $183 \mathrm{bp}$

Lane $3 \& 4$ : SLT2 gene, 346 bp and 66 samples of chicken meat were collected randomly (Random Sampling Method). From these samples, muscle pieces were separated into sterile bags by using sterile forceps and scissors and transported by maintaining cold.

Identification of E. coli: The surfaces of chicken muscles were incised with scissor and $10 \mathrm{gm}$ muscle was mixed with $90 \mathrm{ml}$ of NSS in sterile bag. Thereafter, serially diluted the sample from $10^{-1}$ to $10^{-5}$ then cultured on Eosin Methylene Blue (EMB) agar (HiMedia, India) and incubated for 18 to $24 \mathrm{~h}$ at $37^{\circ} \mathrm{C}$. Colonies with green metallic sheen were considered $E$. coli and biochemically tested for indole production, glucose degradation, tryptophan degradation, citrate utilization, urease production and for motility and growth on triple sugar iron agar (TSI). These isolates of E. coli were stored in Nutrient agar (HiMedia, India) slants till use.

DNA extraction: DNA of $E$. coli was isolated by Cetyl Trimethyl Ammonium Bromide (CTAB) method as described by Wilson [11] with slight modifications. Five $\mathrm{ml}$ LB broth (HiMedia, India) culture of E. coli were incubated at $37^{\circ} \mathrm{C}$ overnight. Three ml culture was taken in microcentrifuge tube and pelleted by centrifugation at 10,000 rpm for 5 minutes. Pellet was resuspended in $567 \mu \mathrm{l}$ of TE buffer, added $0.5 \%$ SDS (SRL, India) and $100 \mu \mathrm{g} / \mathrm{ml}$ proteinase K (SRL, India), mixed thoroughly and incubated for 1 hour at $37^{\circ} \mathrm{C}$. Added $100 \mu \mathrm{l}$ of $5 \mathrm{M} \mathrm{NaCl}$ (SRL, India) to cell lysate and mixed thoroughly. Thereafter, $80 \mu$ l of $\mathrm{CTAB} / \mathrm{NaCl}$ (SRL, India) solution was added and incubated at $65^{\circ} \mathrm{C}$ for 10 minutes. Equal volume $(0.7$ to $0.8 \mathrm{ml})$ of Phenol/Chloroform/Isoamyl-alcohol (25:24:1) was added and centrifuged for 5 minutes at $13000 \mathrm{rpm}$. Thereafter, the upper aqueous, viscous supernatant was transferred to fresh tubes then 0.5 volume of $7.5 \mathrm{M}$ ammonium acetate (SRL, India) and double amount of chilled absolute ethanol were added. The tubes were kept at $-20^{\circ} \mathrm{C}$ for overnight, obtained pellet by centrifugation for 20 minutes at $4^{\circ} \mathrm{C}$ at $13,000 \mathrm{rpm}$ and washed with 70\% ethanol (SDFCL, India). The pellet was dried by keeping tubes open and resuspended in 50 $\mu 1$ of elution buffer. Finally, DNA integrity was assessed by running in $1.7 \%$ agarose (HiMedia, India) gel. Extracted DNA was stored at $-20^{\circ} \mathrm{C}$ till further use.

Primers: The presence of virulence associated genes i.e. shiga-like toxin (SLT1and SLT2), heat stable toxin (STa) and heat labile toxin (LT) of E. coli were determined by PCR. Primers used for associated genes are depicted in Table-1.

Detection of virulent genes by PCR: The PCR reaction for amplification of SLT1, SLT2, STa and LT genes was done in standard $25 \mu 1$ reaction in $0.2 \mathrm{ml}$ PCR tube (Axygen, USA), separately. $2 \mu$ of DNA was used as template. 20 picomolar solution of each primer (Sigma, India), 1X Taq amplification buffer, (SRL, India), $1 \mathrm{mM} \mathrm{MgCl} 2,200 \mu \mathrm{M}$ each nucleotides (SRL, India) and 1.25 units of Taq DNA polymerase (SRL, India) were used for each reaction. The mixture containing PCR tubes were quickly spun at $10000 \mathrm{rpm}$ for few seconds and placed in gradient thermal cycler (Eppendorf, Germany). The cycling conditions for amplification included $94^{\circ} \mathrm{C}$ for 3 minute (initial denaturation), 30 cycles of $94^{\circ} \mathrm{C}$ for 1 minute (denaturation), annealing for 1 minute (annealing temperature shown in Table 1 ) and $72^{\circ} \mathrm{C}$ for 1 minute (polymerization) followed by $72^{\circ} \mathrm{C}$ for 10 minute (final extension). The positive amplification was visualized by electrophoresis of the product in $1.7 \%$ agarose (HiMedia, India) gel stained with ethidium bromide in a submarine horizontal electrophoresis apparatus (Bangalore Genei).

Serotyping of E. coli: $E$. coli isolates obtained from chicken meat were sent to Central Research Institute, Kasauli, HP, for serotypes differentiation.

\section{Results}

Out of 66 chicken meat samples analysed, 11 (16.66\%) samples showed presence of $E$. coli isolates (Incidence 16.66\%). Regarding the results of PCR, shiga like toxin-2 was found in $3(27.27 \%)$ and heat stable toxin in $2(18.18 \%)$ of the 11 positive $E$. coli 
isolates (Figure 1). In other words, frequency of shiga like toxin and heat stable toxin gene was $27.27 \%$ and $18.18 \%$ respectively. None of the heat labile toxin gene associated $E$. coli isolates was identified in this study. The total identified virulent strains were 5 among 11 investigated strains $(45.45 \%)$. As a result, overall incidence of virulent strains of $E$. coli was $7.57 \%$ (ETEC, 3.03\% and STEC, 4.54\%) (5 virulent strains out of $11 E$. coli strains isolated from 66 samples). In addition, all $E$. coli strains were serotyped in which 5 isolates were confirmed as rough, O2, O20, O22 and O102 while rest of the 6 isolates were untypable (UT).

\section{Discussion}

The prevalence of ETEC and STEC strains and frequency of associated virulent genes were explored among $E$. coli isolates obtained from chicken meat (collected from chicken retail shops) in Mumbai city, India. Virulent genes of $E$. coli strains were commonly found in chicken meat, which necessitate routinely monitoring of $E$. coli strains isolated from food. In the present study, frequency of ETEC associated genes was found $18.18 \%$ of total isolates. Similar study carried out in Iran, there frequency of ETEC strains associated genes were $25.2 \%$ reported, which is not in agreement with the our findings wherein frequency was lower [14]. This type of variance may be because of small sample size under the present investigation. Moreover, $3.03 \%$ incidence was observed for enterotoxigenic $E$. coli obtained from 66 samples of chicken meat. Similar to this observation, previous reports from India have varied findings for prevalence of ETEC ranging from $0.92 \%$ to $12 \%$ [15-17]. In India information regarding the STEC is available on cattle, sheep, fish, human feces but information related to STEC prevalence in chicken meat is rare. In the present study STEC associated genes frequency was found $27.27 \%$ of total isolates. In this investigation, very low proportion of STEC strains were isolated (Incidence $4.54 \%$ ). These data is consistent with the low prevalence of STEC infection in India [17, 18]. Previous reports have confirmed that food transmission of STEC has little significance, estimated prevalence ranges from 0 to $11.1 \%$ [19, 20]. Along with, most studies focused on STEC strains of $E$. coli revealed that chicken meat is a major source for exposure of these strains to human population [21-23]. Here prevalence of ETEC and STEC strains and frequency of associated virulent genes of $E$. coli strains in chicken meat was reported. In traditional microbiology usually $E$. coli determination carried out as numbers/gram without characterizing the strains isolated. But in this study incidence of virulent strains of $E$. coli showed that there is need for necessary measures to protect consumer health by forwarding these necessary information to higher authorities and thus to facilitate necessary action required to protect public health by preventing poor hygienic practices that increases the prevalence of food pathogens [24].

\section{Conclusion}

The results concluded that chicken meat samples analyzed were harbored virulent genes for shiga like toxins and enterotoxins. It pointed out that chicken meat contaminated with $E$. coli strains in such level could produce potential hazard for consumers. Next to that, further exploration of other virulent strains like enteroinvasive $E$. coli (EIEC), enteropathogenic $E$. coli (EPEC), enteroaggregative E. coli (EAggEC) are needed to know the particular situation of $E$. coli contaminated chicken meat at local market.

\section{Authors' contributions}

RJZ, DMC, PRS executed the study design and analyzed the data. RJZ supervised the work and edited the paper. DMC collected samples and interpreted the results. PRS and AKR performed the experiments. AKR drafted and revised the manuscript. VMV assisted in the designing and performance of PCR. All authors discussed implications, results and finalized the manuscript. All authors read and approved the manuscript.

\section{Acknowledgements}

The authors are thankful to the Indian Council of Agricultural Research, New Delhi, India for providing funds and necessary facilities through the project entitled "All India Coordinated Research Project on Post Harvest Technology" (Grant no.-F.No.2 (37)/ 2009/PHT Date: 21.07.2009) to carry out part of work.

\section{Competing interests}

The authors declare that they have no competing interests.

\section{References}

1. Udaykar, A., Sharda, R., Chhabra, D. and Sharma, V. (2009) Study of virulence factors of Escherichia coli strains isolated from diarrhoeic calves. Indian J. Comp. Microbiol. Immunol. Infect. Dis., 30: 26-28.

2. Chansiripornchai, N. (2009) Comparative efficacy of enrofloxacin and oxytetracycline by different administra-tion methods in broilers after experimental infection with avian pathogenic Escherichia coli. Thai J. Vet. Med., 39: 231-236.

3. Ferens, W.A. and Hovde, C.J. (2011) Escherichia coli O157:H7: animal reservoir and sources of human infection. Food-borne Pathog. Dis., 8: 465-485.

4. Nataro, J.P. and Kaper, J.B. (1998) Diarrheagenic Escherichia coli. Clin. Microbiol. Rev., 11: 142-201.

5. Nweze, E.I. (2009) Virulence properties of diarrheagenic $E$. coli and etiology of diarrhea in infants, young children and other age groups in southeast, Nigeria. American-Eurasian J. Sci. Res., 4: 173-179.

6. Gyles, C.L. and Fairbrother, J.M. (2004) Escherichia coli. pages: 160-193. In: Gyles, CL;Prescott, JF; Songer, JG and Theon, CO (Eds.), Pathogenesis of bacterial infections in animals. (3rd Edn.), Ames, Iowa, Blackwell Publishing. PP: 145-214.

7. Coombes, K.B., Wickham, E.M., Mascarenhas, M., Gruenheid, S., Finlay, B.B. and Karmali, A.M. (2008) Molecular analysis as an aid to assess the public health risk of non-O157 shiga toxin-producing Escherichia coli strains. Appl. Environ Microbiol., 74: 2153-2160.

8. Pradel, N., Bertin, Y., Martin, C. and Livrelli, V. (2008) Molecular analysis of shiga toxin-producing Escherichia coli strains isolated from hemolytic uremic syndrome 
patients and dairy samples in France. Appl. Environ. Microbiol., 74: 2118-2128.

9. Chapman, P., Chapman, A., Cerdan Malo, A.T., Ellin, M., Ashton, R. and Harkin, M.A. (2001) Escherichia coli O157 in cattle and sheep at slaughter, on beef and lamb carcasses and in raw beef in raw beef and lamb products in South Yorkshire, UK Int. J. Food Microbiol., 64:139-150.

10. Omisakin, F., Macrae, M., Ogden, I.D. and Strachan, N.J. (2003) Concentration and prevalence of Escherichia coli O157 in cattle feces at slaughter. Appl. Environ. Microbiol., 69: 2444-2447.

11. Wilson, K. (1987) Preparation of genomic DNA from bacteria. Current protocols in molecular biology, Unit 2.4.1, New York, Wiley.

12. Pollard, D.R., Johnson, W.M., Lior, H., Tyler, S.D. and Rozee, K.R. (1990) Rapid and specific detection of verotoxin genes in Escherichia coli by the polymerase chain reaction. J. Clin. Microbiol. 20: 540-545.

13. Nguyen, T.L., Truong, H.T. and Nguyen, V.G. (2009) Determining virulence factors of Escherichia strains isolated from diarrhea piglets by using PCR method. J. Sci. Dev., 7: 187:191.

14. Bonyadian, M., Moshtaghi, H., Nematalahi, A., Rahimi, E., Akhavan Taheri, M. and Karami, S. (2011) Isolation of enterotoxigenic and enteroaggregative straines of Escherichia coli from chicken carcasses by PCR. Iranian J. Vet. Res., 12: 252-255.

15. Kiranmayi, C.B. and Krishnaiah, N. (2010) Detection of Escherichia coli $\mathrm{O} 157: \mathrm{H} 7$ prevalence in foods of animal origin by cultural methods and PCR technique. Veterinary World, 3: 13-16.

16. Dutta, T.K., Roychoudhury, P., Sadhukhan, T.K., Ghosh, A. and Bandyopadhaya, A.G. (2010) Detection and characterization of shigatoxigenic E. coli (STEC) and entero- pathogenic Escherichia coli (EPEC) from diarrhoeic piglets in an organized farm in Kolkata. Indian J. Anim. Sci., 80: 493-496.

17. Wani, S.A., Nabi, A., Fayaz, I., Ahmad, I., Nishikawa, Y., Qureshi, K., Khan M.A. and Chowdhary, J. (2006) Investigation of diarrhoeic faecal samples for enterotoxigenic shiga toxin-producing and typical or atypical enteropathogenic Escherichia coli in Kashmir, India. FEMS Microbiol. Lett., 261:238-244.

18. Danashree, B. and Mallya, P.S. (2008) Detection of shigatoxigenic Escherichia coli (STEC) diarroeagenic stool and meat samples in Mangalore, India. Indian J. Med. Res., 128: 271-277.

19. Vivegnis, J., Lioui, M., Leclercq, A., Lambert, B. and Decallonne, J. (1999) Detection of Shiga-like toxin producing Escherichia coli from raw milk cheeses produced in Wallonia. Biotechnol. Agron. Soc. Environ., 3: 159-164.

20. Coia, J., Johnston, Y., Steers, N. and Hanson, M. (2001) A survey of the prevalence of Escherichia coli $\mathrm{O} 157: \mathrm{H} 7$ in raw meats, raw cow's milk and raw-milk cheeses in south-east Scotland. Int. J. Food Microbiol. 66: 63-69.

21. Tutenel, A.V., Pierard, D., Van Hoof, J. Cornelis, M. and De Zutter, L. (2003) Isolation and molecular characterization of Escherichia coli $\mathrm{O} 157$ isolated from cattle, pigs and chickens at slaughter. Int. J. Food Microbiol., 84: 63-69.

22. Akkaya, L. Atabay, H.I., Kenar, B. and Alisarli, M.. (2006) Prevalence of verotoxigenic E. coli O157:H7 on chicken carcasses sold in Turkey. Bul. Vet. Ins. Pulawy., 50: 513-516.

23. Ghanbarpour, R., Salehi, M. and Oswald, E. (2010) Virulance genotyping of E. coli isolates from avian cellulitis in relation to phylogeny. Com. Clin. Pathol., 19: 147-153.

24. Cohen, N., Ennaji, H., Hassar, M. and Karib, H. (2006) The bacterial quality of red meat and offal in Casablanca (Morocco). Mol. Nut. Food. Res., 50: 557-562.

$* * * * * * * *$ 